\title{
Whole plant open chamber to measure gas exchange on herbaceous plants
}

Florencia Noemī Ferrari ${ }^{1 *}$, Carlos Alberto Parera ${ }^{1}$, and Carlos Bernardo Passera²

\section{ABSTRACT}

Much of our understanding about $\mathrm{CO}_{2}$ and $\mathrm{H}_{2} \mathrm{O}$ gas exchange in plants has been gained from studies at leaf level. Extrapolation of results to whole plant is difficult and not always accurate. In order to overcome this limitation, a chamber was designed to measure gas exchange at the whole plant level. The chamber developed in this work consisted on an acrylic cylinder 0.70 $\mathrm{m}$ high and $0.60 \mathrm{~m}$ wide. An incorporated blower was used to circulate air through the chamber and plant canopy from the bottom inlet upwards to the outlet tube providing a maximum flow of $0.072 \mathrm{~m}^{3} \mathrm{~s}^{-1}$. Air $\mathrm{CO}_{2}$ and water concentration were monitored with an infrared gas analyzer and temperature gradients were measured periodically with sensors. Air flow rates inside the chamber were $0.007,0.012,0.022,0.047$, and $0.072 \mathrm{~m}^{3} \mathrm{~s}^{-1}$. A comparative study showed that 0.022 or 0.047 $\mathrm{m}^{3} \mathrm{~s}^{-1}$ air flow rates did not modify substantially the natural environment within the chamber; measurements are close to real and exterior ones; temperature increased below 4 ${ }^{\circ} \mathrm{C}$; photosynthetically active radiation (PAR) was reduced by $5 \%$; and photosynthesis and evapotranspiration showed mean values with nonsignificant variations $(22 \pm 3.8 \mu \mathrm{mol}$ $\mathrm{CO}_{2} \mathrm{~m}^{-2} \mathrm{~s}^{-1}$, and $15 \pm 4.0 \mathrm{mmol} \mathrm{H}_{2} \mathrm{O} \mathrm{m}^{-2} \mathrm{~s}^{-1}$, respectively). This chamber could be a useful tool to measure gas exchange of whole plants in herbaceous species under conditions of high evapotranspiration and for extended periods of time.

Key words: Carbon dioxide, evaporation, evapotranspiration, photosynthesis, temperature.

Instituto Nacional de Tecnología Agropecuaria, INTA MendozaSan Juan, San Martín 3853, Mendoza (CP 5507), Argentina. "Corresponding author (ferrari.florencia@inta.gob.ar).

${ }^{2}$ Universidad Nacional de Cuyo, Facultad de Ciencias Agrarias, Almirante Brown 500, Mendoza (CP 5507), Argentina.

Received: 13 April 2015.

Accepted: 21 September 2015.

doi:10.4067/S0718-58392016000100013

\section{INTRODUCTION}

Cropland in Mendoza, Argentina, include arid and semiarid ecosystems with very high evapotranspiration during summer (in the range of 6 to $7 \mathrm{~mm} \mathrm{~d}^{-1}$ ) (Catania et al., 2012; Uliarte et al., 2014). Water for irrigation is scarce and limits the expansion of agriculture in the region. Associated changes in climate during the coming decades, e.g. warming and reduce water availability, are expected to increase evaporative demand and actual transpiration (Hutchinson et al., 2007; IPCC, 2007; Labraga and Villalba, 2009; Lal, 2011). Therefore, the importance of developing techniques to accurately measure gas exchange of whole plants is imperative to anticipate irrigation requirements by herbaceous species in future climates.

Several portable chambers to measure plant gas exchange properties in the field have been developed in recent decades. Some chambers have been designed as closed or semiclosed systems (Pérez-Priego et al., 2010); plants are placed in a sealed enclosure and changes in $\mathrm{CO}_{2}$ and water vapor concentration over a period of time is used to estimate photosynthesis and evapotranspiration. These systems impose changing conditions for plants located inside, and they are used for short periods of time (a few minutes). Longer measurements require an effective control of the microclimate in the chamber, a technology that would considerably increase the cost of the measuring device (Burkart et al., 2007). Open systems, in contrast, are cheaper to run and have continuous ventilation, which allows more accurate gas exchange measurements for days or weeks (Burkart et al., 2007; Poni et al., 2014). Open chambers have been extensively used under field conditions to determine gas exchange at the whole plant in trees (Medhurst et al., 2006; Barton et al., 2010), shrubs (Stannard and Weltz, 2006), and herbaceous crops (Balogh et al., 2007; Burkart et al., 2007; Müller et al., 2009). These studies have mainly assessed the effects of crop management (e.g. irrigation, soil and canopy management) or environmental factors on photosynthesis and evapotranspiration measurements (Burkart et al., 2007; Barton et al., 2010).

There are some other reliable techniques for measuring soil-surface $\mathrm{CO}_{2}$ fluxes or whole plant gas exchange. Micrometeorological methods (e.g. eddy covariance) may provide results more or less comparable with gas exchange chambers (Myklebust et al., 2008; Schrier-Uijl et al., 2010); nevertheless, these technologies require large homogeneous areas. More recent determinations of evapotranspiration flux $(E)$ using energy balance 
(Micro-Bowen ratio system) overcame this limitation but it did not estimate $\mathrm{C}$ gas exchange (Holland et al., 2013). Open chambers can be used to continuously measure whole plant gas exchange for experiments in small plots (Burkart et al., 2007). They are less expensive, easier to transport and assemble than micrometeorological systems (Burkart et al., 2007; Varela et al., 2010); however, there are secondary effects associated with the enclosure. Experimental artifacts in controlled environments often include (i) reduced total radiation (Müller et al., 2005; Burkart et al., 2007; Centinari et al., 2009), (ii) increased diffuse radiation (Müller et al., 2009), (iii) altered vapor pressure deficit (VPD) (Balogh et al., 2007) and wind speed (Bonada and Sadras, 2015). These changes in irradiance, in diffuse light and VPD because of the enclosure will affect gas exchange and $\mathrm{C}$ assimilation (Müller et al., 2005; Burkart et al., 2007; Centinari et al., 2009). There is possible, however, to minimize these undesirable effects with an appropriate air flow and chamber design (Balogh et al., 2007; Burkart et al., 2007; Bonada and Sadras, 2015).

An open chamber system for whole plants is essentially similar to a leaf chamber (Alterio et al., 2006). Leaf chambers do not take into account possible compensation between different leaf stages, types, and light exposure. Singles leaves have different contribution on whole plant $\mathrm{C}$ and $\mathrm{H}_{2} \mathrm{O}$ balances; therefore using leaf chambers is impossible to calculate the transpiration of whole plants during long periods (Barton et al., 2010).

In the open chamber systems air is continuously blown into the enclosure and $\mathrm{C}$ exchange and water loss from plants can be estimated by monitoring the changes in humidity and $\mathrm{CO}_{2}$ concentration with an infrared gas analyzer (IRGA) (Burkart et al., 2007; Centinari et al., 2009). The difference between $\mathrm{H}_{2} \mathrm{O}$ and $\mathrm{CO}_{2}$ concentration of incoming and outgoing air allows for the estimation of $E$ and $\mathrm{CO}_{2}$ exchange or net photosynthesis $\left(P_{\mathrm{N}}\right)$ (Alterio et al., 2006; Varela et al., 2010). The positive pressure generated within the chamber can minimize or even eliminate any $\mathrm{CO}_{2}$ efflux from soil due to respiration from roots or microorganisms (Burkart et al., 2007). Transpiration from herbaceous crops and water evaporation from soil occur simultaneously and the cumulative effect of both processes are quantified together with whole canopy chambers (Centinari et al., 2009).

This paper describes the construction and performance of a portable open chamber to measure gas exchange on cover crops or herbaceous plants in semiarid regions with high evaporative conditions.

\section{MATERIALS AND METHODS}

\section{Construction and operation of the chamber}

The cylindrical chamber of $0.28 \mathrm{~m}^{2}$ circular section and 0.70 $\mathrm{m}$ tall $\left(0.196 \mathrm{~m}^{3}\right)$ was made of $0.005 \mathrm{~m}$ thick transparent acrylic (polymethylmethacrylate) (Figure 1). Dimensions
Figure 1. Open chamber system prototype scheme.

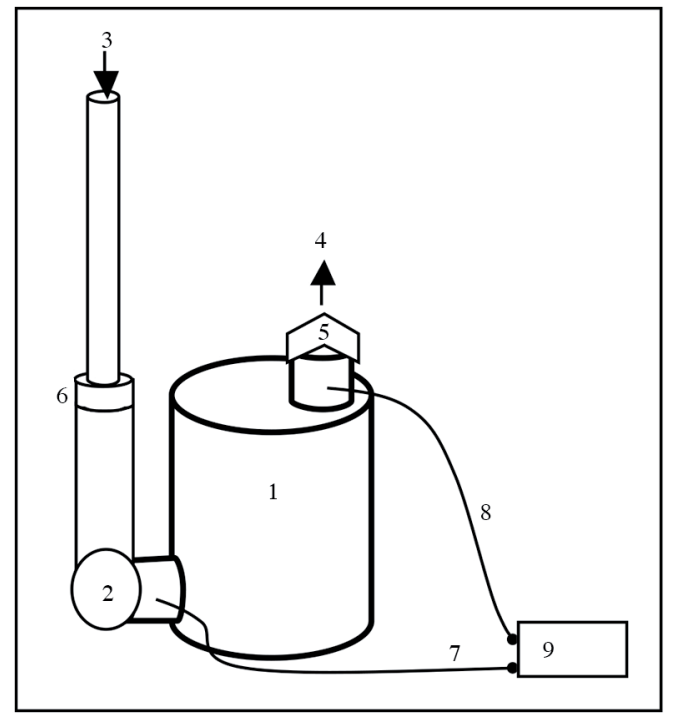

1: Acrylic cylindrical body, 2: alternating current fan, 3 : plastic pipe for inner air, 4: plastic pipe for outlet air, 5: plastic baffle, 6: plastic reduction, 7: reference air sample, 8 : analysis air sample, 9: infrared gas analyzer (IRGA).

were chosen in order to achieve the lowest possible variability in gas exchange measurements (Czóbel et al., 2005). This acrylic is UV-resistant and impermeable, it has less than $10 \%$ of thermal transmission and only absorbs approximately $0.014 \%$ of water vapor per hour.

Ambient air was continuously blown into the chamber by an alternating current fan (Ital Air, Buenos Aires, Argentina). The air entered into the chamber through a plastic pipe $(0.16$ $\mathrm{m}$ diameter) located $0.10 \mathrm{~m}$ above the ground and exited through another pipe located on the top of the chamber. A baffle was placed on the outlet pipe to exclude direct incursion of wind. The air flow rate $(F)$ was varied by replacing the inlet air pipe with others of different diameter (0.120, 0.050, 0.045 , and $0.040 \mathrm{~m}$ ) of at least $1.00 \mathrm{~m}$ long. All plastic pipes were white to reduce radiation absorption and temperature fluctuations of the incoming air (Burkart et al., 2007).

Gas samples from inlet and outlet tubes were taken by the infrared gas analyzer (IRGA, Portable Photosynthesis System CIRAS-2, PP Systems, Amesbury, Massachusetts, USA) to measure the corresponding $\mathrm{CO}_{2}$ and $\mathrm{H}_{2} \mathrm{O}$ concentrations. A small fan (0.075 m diameter; MJ 802512, Brushless, HsinTien City, Taipei Hsien, Taiwan, China) was placed inside the chamber to obtain mixed and representative samples of air, and to prevent convection currents. Air flow through the chamber was determined using a hot-wire anemometer (series 471, Dwyer, Michigan City, Indiana, USA) in the cross section of the inlet tube (Balogh et al., 2007).

Two data loggers fitted with thermometers (TC1047A, Cavadevices, Buenos Aires, Argentina) and a quantum photosynthetically active radiation (PAR) sensors (cell: GaAsP with aluminum encapsulation) recorded information every minute and averaged it every $15 \mathrm{~min}$. The inside PAR sensor was placed in the middle of the chamber at $0.60 \mathrm{~m}$ 
from the ground (to avoid shade from plants), and the outside sensor was placed on the soil surface without shade. Both light sensors were placed parallel to the soil surface. The temperature sensors were located $0.30 \mathrm{~m}$ above the ground, and protected from radiation by an aluminum sheet.

The equations used to calculate $P_{\mathrm{N}}$ (net photosynthesis) and $E$ from plants were adapted from Centinari et al. (2009) and Burkart et al. (2007):

$$
E=u / A \times\left[\Delta e /\left(P-e_{\mathrm{o}}\right)\right]
$$

where $E$ is the evapotranspiration $\left(\mathrm{mmol} \mathrm{H} \mathrm{H}_{2} \mathrm{O} \mathrm{m}^{-2} \mathrm{~s}^{-1}\right), u$ is the molar flux (mol H$\left.{ }_{2} \mathrm{O} \mathrm{s}^{-1}\right), A$ is the chamber surface $\left(\mathrm{m}^{2}\right)$, $\Delta e$ is the vapor pressure difference between incoming and outgoing air $(\mathrm{Pa}), \mathrm{P}$ is the atmospheric pressure (assumed constant $101325 \mathrm{~Pa}$ ), and $e_{\mathrm{o}}$ is the vapor pressure outside of the chamber $(\mathrm{Pa})$.

$$
P_{\mathrm{N}}=\Delta \mathrm{CO}_{2} \times u / A
$$

$P_{\mathrm{N}}$ is the $\mathrm{CO}_{2}$ exchange or net photosynthesis $\left(\mu \mathrm{mol} \mathrm{CO} \mathrm{CO}_{2}\right.$ $\left.\mathrm{m}^{-2} \mathrm{~s}^{-1}\right), \Delta \mathrm{CO}_{2}$ is the $\mathrm{CO}_{2}$ concentration difference determined by IRGA in the incoming and outgoing air, and $u$ is the molar flux $\left(\mathrm{mol} \mathrm{CO}_{2} \mathrm{~s}^{-1}\right)$, and $A$ is the same as above:

$$
u=(F \times P) /\left(R \times T_{\mathrm{o}}\right)
$$

where $u$ is the molar flux $\left(\mathrm{mol} \mathrm{s}^{-1}\right), F$ is the air flow rate $\left(\mathrm{m}^{3} \mathrm{~s}^{-1}\right), T_{\mathrm{o}}$ is the ambient temperature $(\mathrm{K}), \mathrm{R}$ is the universal gas constant $8.3145 \mathrm{~Pa} \mathrm{~m}^{3} \mathrm{~mol}^{-1} \mathrm{~K}^{-1}$, and $P$ is the atmospheric pressure $(\mathrm{Pa})$.

\section{Assessment of evaporation}

A gravimetric method with Petri dishes filled with water was used to calibrate the evaporation from the chamber. The chamber was located on a white-waterproof surface. Six Petri dishes of $0.09 \mathrm{~m}$ diameter were filled with $25 \mathrm{~g}$ water and half of them placed either inside or outside the chamber. The inside evaporation was calculated by using a gravimetric method (IG) and chamber method (IC) (with the IRGA); and the outside evaporation was calculated with the gravimetric method (OG).

The evaporation measurements were performed during $30 \mathrm{~min}$ for each $F(0.007,0.012,0.022,0.047$, and 0.072 $\mathrm{m}^{3} \mathrm{~s}^{-1}$ ) and four replicates were performed for each one. The ratio between evaporation measured by chamber method and gravimetric method inside the chamber was calculated (IC/ IG); and the ratio between the inner measurement determined by chamber method and the outer evaporation determined by gravimetric method was also estimated (IC/OG). Measurements were carried out under clear sky conditions between 10:00 and 16:00 h for $2 \mathrm{~d}$ in December 2012, and no water vapor condensation was observed on the walls of the chamber. Temperature and light inside and outside the chamber were recorded every $15 \mathrm{~min}$. Data $\log$ of $\mathrm{CO}_{2}$ and $\mathrm{H}_{2} \mathrm{O}$ amounts were done every $15 \mathrm{~s}$ by the IRGA.

\section{Effect of $F$ on $P_{\mathrm{N}}$ and $E$ from a cover crop}

Gas exchange experiment was conducted to select an appropriate $F$ rate for a more accurate chamber operation.
The study was performed on an irrigated cover crop that was $0.05 \mathrm{~m}$ tall and the coverage was composed of $79 \%$ Cynodon dactylon (L.) Pers. var. dactylon and $21 \%$ Taraxacum officinale F.H. Wigg aggr.*, both species were at vegetative stage; groundcover was measured with the beaded-string method used by Uliarte et al. (2013). The experimental site was located at the agricultural research station of INTA in Mendoza, Argentina (3300'21' S, 68 51'53” W).

Measurements of $P_{\mathrm{N}}$ and $E$ were done using each $F(0.007$, $0.012,0.022,0.047$, and $\left.0.072 \mathrm{~m}^{3} \mathrm{~s}^{-1}\right)$. The evaluations were repeated 4 times, and the order of use of $F$ in each repetition was randomized. Determinations were carried out in December 2012, during 2 d with clear sky between 10:00 and 16:00 h. $P_{\mathrm{N}}$ and $E$ were calculated using averages of measured $\mathrm{CO}_{2}$ and $\mathrm{H}_{2} \mathrm{O}$ amounts over 30 min (Equations [1] and [2]). Data $\log$ of $\mathrm{CO}_{2}$ and $\mathrm{H}_{2} \mathrm{O}$ concentrations were done every $15 \mathrm{~s}$ by the IRGA. For each $F$, it was calculated the temperature difference $(\Delta \mathrm{T})$ between chamber interior and exterior, and the difference between VPD outside and inside the chamber $(\triangle \mathrm{VPD})$.

\section{Gas exchange from a cover crop with a selected $F$}

Measurements of gas exchange were carried out on the same cover crop as during comparison of air flow rates with $F$ $0.022 \mathrm{~m}^{3} \mathrm{~s}^{-1}$ and all parameters measured as before. There were calculated $E$ and $P_{\mathrm{N}}$ (Equations [1] and [2]) from the cover crop.

Determinations began at 08:30 h, and finished at 17:30 h in February 2013. There was an episode of clouds between 08:30 and 09:30 h. Then, the sky was completely clear until the end of the measurements. The maximum recorded temperature was $35.8^{\circ} \mathrm{C}$, and daily average relative humidity was $54 \%$.

\section{Statistical analysis}

All data obtained during calibration, comparison of $F$ and cover crop measurements were analyzed by ANOVA using statistical software InfoStat (2011). Normal distribution of data and variance homogeneity of data were tested. Linear regression analyses were performed between gas exchange fluxes, $\Delta \mathrm{T}$, and $\triangle \mathrm{VPD}$ according to $F$. Pearson coefficient was calculated to assess the correlation between the gas exchange fluxes $\left(E, P_{\mathrm{N}}\right)$ and $F, T$, and PAR light.

\section{RESULTS AND DISCUSSION}

\section{Assessment of evaporation}

During evaporation measurements with Petri dishes there were no appreciable fluctuations of PAR incidence, neither air vapor pressure; similar results were obtained by Müller et al. (2009) during their chamber assessment. Therefore, PAR 
and air vapor pressure did not influence evaporation, $E$, and $P_{\mathrm{N}}$ within the chamber. The inside evaporation was measured by using the gravimetric method (IG) and the chamber method with the IRGA (IC). As expected, an increase in the air flow rate inside the chamber increased evaporation, and no significant changes were registered in evaporation outside the chamber determined by gravimetric method (OG) with all $F$ (Figure 2a).

Gravimetric method measurements were higher than $I C$ ones until $0.05 \mathrm{~m}^{3} \mathrm{~s}^{-1}$, but $O G$ remains almost constant. Evaporation inside the chamber followed a linear function reaching a maximum value of $5.6 \mathrm{~g} \mathrm{~h}^{-1}$ when it was determined by IG, and $6.8 \mathrm{~g} \mathrm{~h}^{-1}$ when measured by IC with $F=0.072 \mathrm{~m}^{3} \mathrm{~s}^{-1}$. The maximum evaporation measured by IC (with $0.072 \mathrm{~m}^{3} \mathrm{~s}^{-1}$ ) was 1.2 times higher than IG; but the minimum evaporation measured by IC (with $0.012 \mathrm{~m}^{3} \mathrm{~s}^{-1}$ ) was 2.4 times lower than IG. IG and IC increased when $F$ enhanced, it could be due to a decrease in resistance of the boundary layer on evaporation surface because of air velocity increasing and the turbulence within the chamber (Centinari et al., 2009). These increases in air velocity caused a rise in the water potential gradient between atmosphere and this surface, and evaporation rose too. The increased wind speed within the chamber may increase evaporation from soil surface. Stannard and Weltz (2006) registered large evaporation values from chamber method compared with eddy-covariance method.

Figure 2. A. Evaporation measured by gravimetric method (IG: inside, OG: outside) and by chamber method (IC: inside). B. IC/IG and IC/OG ratios.
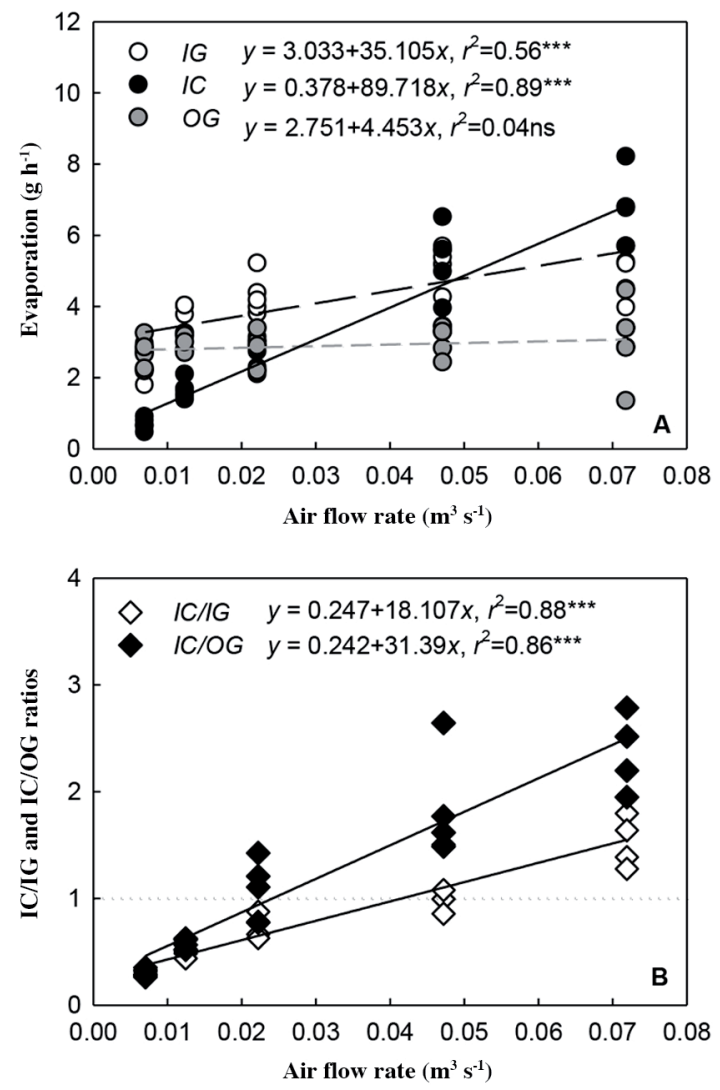

The ratio between inner evaporation determined by chamber method and gravimetric method (IC/IG) was linearly correlated with the $F(p<0.001)$ (Figure 2b). The IC/IG ratios were $0.29,0.49,0.74,1.11$, and 1.61 for 0.007 , $0.012,0.022,0.047$, and $0.072 \mathrm{~m}^{3} \mathrm{~s}^{-1}$, respectively (Figure 2b). IC/IG ratios close to 1 were obtained by using 0.022 and $0.047 \mathrm{~m}^{3} \mathrm{~s}^{-1}$. The mean IC/OG ratios were $0.31,0.58$, $1.13,1.88$, and 2.50 , for $0.007,0.012,0.022,0.047$, and 0.072 $\mathrm{m}^{3} \mathrm{~s}^{-1}$, respectively. As above, the IC/OG ratios close to 1 were obtained by using 0.022 and $0.047 \mathrm{~m}^{3} \mathrm{~s}^{-1}$. IC/IG and IC/OG ratios close to 1 were obtained by using the chamber with 0.022 and $0.047 \mathrm{~m}^{3} \mathrm{~s}^{-1}$. Therefore with these two $F$, the evaporation determined by the chamber (IC) would be close to the real (IG) and similar to the exterior (OG) without modifying conditions within the chamber. The IC/IG values were then used to correct $E$ measurements of plants to each $F$.

After calibration we can ensure that chamber method underestimates the actual gravimetric water loss (with $F<0.05 \mathrm{~m}^{3} \mathrm{~s}^{-1}$ ). Centinari et al. (2009) also founded that measurements from their chamber method slightly underestimate the water loss calculated by gravimetric method. They stated that material of chamber construction does not absorb air moisture, so neither does it the chamber prototype developed during this work.

\section{Effect of $F$ on $P_{\mathrm{N}}$ and $E$ from a cover crop}

The $\Delta \mathrm{T}$ values obtained for $0.022,0.047$, and $0.072 \mathrm{~m}^{3} \mathrm{~s}^{-1}$ were lower than $5{ }^{\circ} \mathrm{C}$ (Figure $3 \mathrm{a}$ ). Low $\Delta \mathrm{T}$ is desirable to make the environment within the chamber representative of the surrounding environment of plants evaluated. The largest $\Delta$ T was 6.74 and $7.08^{\circ} \mathrm{C}$ corresponding to $F 0.007$ and 0.012 $\mathrm{m}^{3} \mathrm{~s}^{-1}$, respectively. The $\Delta \mathrm{T}$ should be below $5{ }^{\circ} \mathrm{C}$ to avoid increasing evapotranspiration due to increasing sensible heat, and prevent substantial modification of natural surrounding environment of plants evaluated within the chamber (Burkart et al., 2007). The $\Delta \mathrm{T}$ could be kept below this limit at $F 0.022$ $\mathrm{m}^{3} \mathrm{~s}^{-1}$ or higher. Changes in $F$ did not modify the irradiance reaching the plants inside the chamber. The mean decreasing irradiance within the chamber was about $5 \%$ for all $F$ tested $(p=0.650)$. Other authors reported percentages from $10.5 \%$ to $20 \%$ (Burkart et al., 2007; Baker et al., 2009; Centinari et al., 2009). Finally, $\triangle$ VPD was negatively correlated with $F(p<0.001)$ (Figure 3a). As expected and due to the increased of temperature, increasing $F$ caused the decrease of the difference of VPD between chamber outlet and inlet; Balogh et al. (2007) found similar results with their chamber. According to these authors, the level of $F$ should be high to increase reliability of chamber measurements to match those under natural conditions.

The values of $P_{\mathrm{N}}$ and $E$ of the cover crop were obtained with low scatter, and both increased almost three-fold and five-fold (respectively) throughout the range of air flow tested in a linear trend with similar slopes (Figure $3 \mathrm{~b}$ ). The correlation between of $P_{\mathrm{N}}$ and $E$ with $F$ were 0.93 and 0.96 , respectively (Pearson coefficient $=r$ ). However, Centinari et al. (2009) registered a exponential model of $E$ when 
Figure 3. A. Vapor pressure deficit difference $(\triangle \mathrm{VPD})$ between outer and inner air; temperature difference of air inside and outside of the chamber $(\Delta T)$. B. Evapotranspiration $(E)$ and net photosynthesis $\left(P_{\mathrm{N}}\right)$ of cover crop.
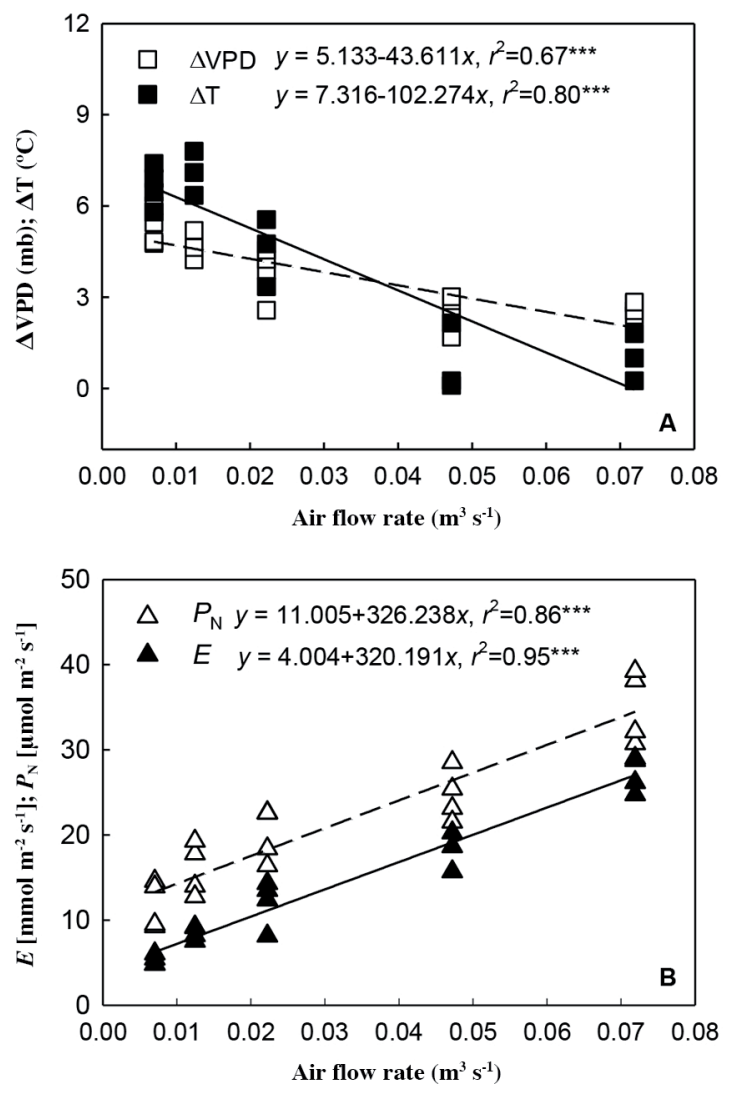

incrementing $F$ in grass cover crops $\left(\mathrm{R}^{2}=0.99\right)$. Poni et al. (2014) found a gravimetric vine water loss highly correlated with chamber-derived vine transpiration $(r=0.95)$.

Therefore, considering an increase of temperature within the chamber $<4^{\circ} \mathrm{C}$, low values of $\triangle \mathrm{VPD}$, and evaporation (IC) with low variability and near to actual (IG) and to the exterior $(\mathrm{OG})$, the appropriated $F$ for accurate operation of the chamber were 0.022 and $0.047 \mathrm{~m}^{3} \mathrm{~s}^{-1}$. Chamber may have some limitations if it would be used with less than $0.022 \mathrm{~m}^{3} \mathrm{~s}^{-1}$; internal temperature could rise above $5{ }^{\circ} \mathrm{C}$, internal VPD could increase, and gas exchange fluxes would be unreliable.

\section{Gas exchange from a cover crop with a selected $\boldsymbol{F}$}

Measurements of cover crop gas exchange during a day were made using $F=0.022 \mathrm{~m}^{3} \mathrm{~s}^{-1}$. This assessment was carried out on February 2012 under high environmental evaporative demands (high temperature and low relative humidity). Temperature inside the chamber was higher than outside, especially between 13:00 and 15:00 $\mathrm{h}$, where it reached a $3.4^{\circ} \mathrm{C}$ averaged difference (Figure $4 \mathrm{a}$ ); although the mean $\Delta \mathrm{T}$ was $2.4^{\circ} \mathrm{C}$. The cloudiness episode caused a decrease of both temperature and radiation received, and consequently gas exchange of the cover crop was affected during $1 \mathrm{~h}$.
Figure 4. Evolution of variables through the time in hours: A. Temperature (T) inside and outside; photosynthetically active radiation (PAR) inside and outside of the chamber. $B$. Net photosynthesis $\left(P_{\mathrm{N}}\right)$ and evapotranspiration $(E)$ from cover crop \pm SD.
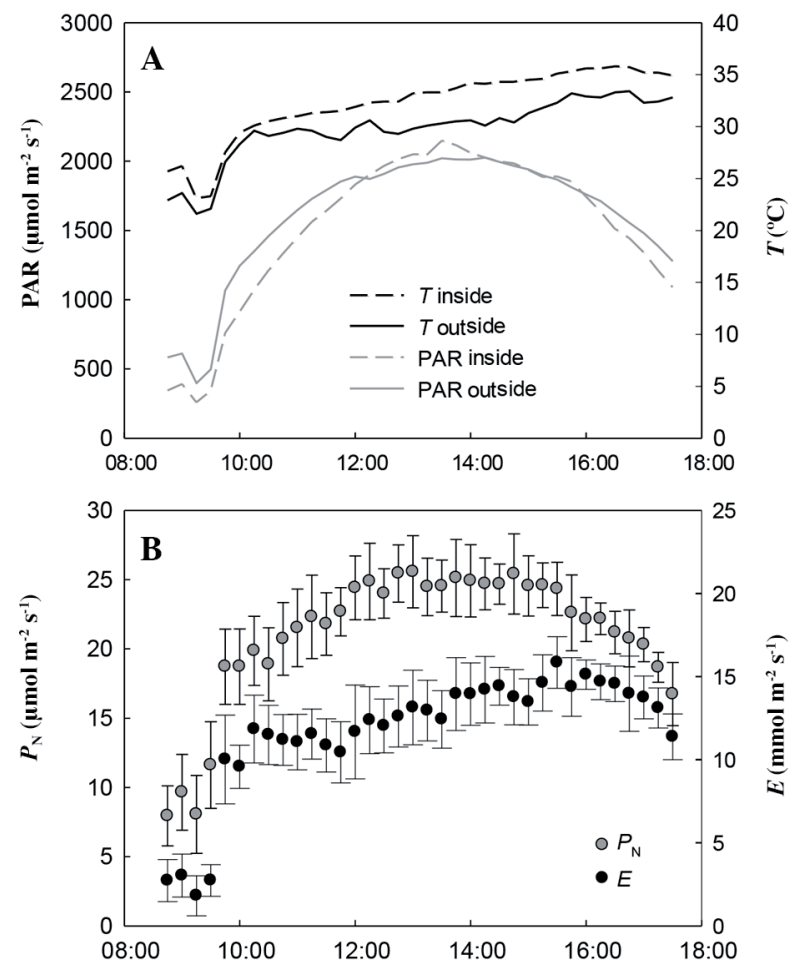

The PAR light inside the chamber was generally lower than outside. The $E$ evolved very similar to the inner temperature (Figure 4b). Correlation between $E$ and temperature and between $E$ and PAR were both high: $\mathrm{r}=0.94$ and $\mathrm{r}=0.83$, respectively $(p<0.001)$. Maximum $E$ was achieved at 15:30 h; it was $4.3 \mathrm{mmol} \mathrm{H}_{2} \mathrm{O} \mathrm{m}^{-2} \mathrm{~s}^{-1}$.

Evapotranspiration was highly correlated with temperature, but maximum temperature was recorded at 16:30 h and maximum $E$ was achieved 1 h earlier. On the other hand, $P_{\mathrm{N}}$ was highest at midday and it followed a very similar trend to that of PAR with a high and significant correlation ( $\mathrm{r}=0.96)$; the correlation between $P_{\mathrm{N}}$ and $T$ was lower but significant $(\mathrm{r}=0.77)$. The maximum $P_{\mathrm{N}}$ was achieved a few minutes before 14:00 h; it was almost 3.5-fold higher to that of $P_{\mathrm{N}}$ early in the morning $\left(25.7 v s . \sim 7.3 \mu \mathrm{mol} \mathrm{m}^{-2} \mathrm{~s}^{-1}\right.$, respectively) (Figure 4b).

During measurements taken under the cover crop for a day with $F=0.022 \mathrm{~m}^{3} \mathrm{~s}^{-1}$ the $E$ (edited by IC/IG value) was highly correlated with temperature and PAR; Burkart et al. (2007) also found a close relationship between temperature and $E$. The increase in temperature may have caused an increase in the deficit of water vapor in the atmosphere, and thereby increased the $E$ of plants. PAR recorded within the chamber was generally less than ambient except when sun was at its highest position. At that time, acrylic reflection within the chamber may have affected these PAR measurements. Lambers et al. (2008) claim that the daily 
$P_{\mathrm{N}}$ is proportional to received PAR; and in this test $P_{\mathrm{N}}$ and PAR evolved similarly. Burkart et al. (2007) also found high correlation coefficients between these two variables on sugar beet and wheat ( $r=0.92$ and 0.98 , respectively). They found the correlation coefficients slightly lower between $E$ and temperature inside the chamber for the same crops $(\mathrm{r}=0.75$ and 0.71 , respectively). The maximum $P_{\mathrm{N}}$ and the highest record of PAR light were registered at the same time. $P_{\mathrm{N}}$ was more sensitive than $E$ to environmental changes, because $P_{\mathrm{N}}$ decreased faster when light began to decline, compared with decreasing of $E$ when temperature slightly decreases. The correlation between $E$ and PAR was elevated; around 16:00 h $E$ decreased while $T$ was still very high, therefore the reduction $E$ may have been related with PAR decreasing. Apparently when leaves began a stress episode (high temperature, high VPD, or water deficiency) they lessen the photosynthesis (Lambers et al., 2008). However, stomata closure occurs later; therefore $E$ did not decrease until a little later and temperature slightly decreases.

\section{CONCLUSIONS}

With these obtained results, we recommended using this prototype gas exchange chamber with air flow rate (F) 0.022 or $0.047 \mathrm{~m}^{3} \mathrm{~s}^{-1}$ even under high evaporative conditions, like on warmest months in Mendoza, Argentina. The evaluated microclimatic conditions inside the chamber do not change substantially (PAR decreased 5\% and temperature increased $<4{ }^{\circ} \mathrm{C}$ ), and the evaporation within the chamber was close to real and outer ones. The chamber could be useful to measure evapotranspiration flux and $\mathrm{CO}_{2}$ exchange or net photosynthesis for long periods of time in whole herbaceous plants. We recommended corroborating these results in other environmental conditions before starting measurements.

\section{ACKNOWLEDGEMENTS}

The authors would like to thank Alejandro Ambrogetti, for helping with the design and construction of the chamber; Ariel Porro, for helping with the chamber assembly; Marcos Bonada and Martin Uliarte for proofreading and suggestions to improve the manuscript quality; and staff and managers of INTA EEA Mendoza, for providing materials and expertise to carry out this work.

\section{REFERENCES}

Alterio, G., P. Giorgio, and G. Sorrentino. 2006. Open-system chamber for measurements of gas exchanges at plant level. Environmental Science and Technology 40:1950-1955.

Baker, J.T., S. Van Pelt, D.C. Gitz, P. Payton, R.J. Lascano, and B. McMichael. 2009. Canopy gas exchange measurements of cotton in an open system. Agronomy Journal 101:52-59.
Balogh, J., Z. Nagy, S. Fóti, K. Pintér, S. Czóbel, E.R. Péli, et al. 2007. Comparison of $\mathrm{CO}_{2}$ and $\mathrm{H}_{2} \mathrm{O}$ fluxes over grassland vegetations measured by the eddy-covariance technique and by open system chamber. Photosynthetica 45:288-292.

Barton, C.V.M., D.S. Ellsworth, B.E. Medlyn, R.A. Duursma, D.T. Tissue, M.A. Adams, et al. 2010. Whole-tree chambers for elevated atmospheric $\mathrm{CO}_{2}$ experimentation and tree scale flux measurements in south-eastern Australia: The hawkesbury forest experiment. Agricultural and Forest Meteorology 150:941-951.

Bonada, M., and V.O. Sadras. 2015. Review: critical appraisal of methods to investigate the effect of temperature on grapevine berry composition. Australian Journal of Grape and Wine Research 21:1-17.

Burkart, S., R. Manderscheid, and H.J. Weigel. 2007. Design and performance of a portable gas exchange chamber system for $\mathrm{CO}_{2}$ and $\mathrm{H}_{2} \mathrm{O}$ flux measurements in crop canopies. Environmental and Experimental Botany 61:25-34

Catania, C.D., M.S. Avagnina, E.M. Uliarte, R.F. del Monte, y J. Tonietto. 2012. Clima vitícola y tipicidad de los vinos en países iberoamericanos. p. 49-95. In Tonietto, J., V. Sotés, and V.D. Gomez-Miguel (eds.) Clima, zonificación y tipicidad del vino en regiones vitivinícolas iberoamericanas. CYTED, Madrid, España.

Centinari, M., S. Poni, I. Filippetti, E. Magnanini, and C. Intrieri. 2009. Evaluation of an open portable chamber system for measuring cover crop water use in a vineyard and comparison with a mini-lysimeter approach. Agricultural and Forest Meteorology 149:1975-1982.

Czóbel, S., S. Fóti, J. Balogh, Z. Nagy, S. Bartha, and Z. Tuba. 2005. Chamber series and space-scale analysis of $\mathrm{CO}_{2}$ gas-exchange in grassland vegetation: a novel approach. Photosynthetica 43:267-272.

Holland, S., J.L. Heitman, A. Howard, T.J. Sauer, W. Giese, A. Ben-Gal, et al. 2013. Micro-Bowen ratio system for measuring evapotranspiration in a vineyard interrow. Agricultural and Forest Meteorology 177:93-100.

Hutchinson, J.J., C.A. Campbell, and R.L. Desjardins. 2007. Some perspectives on carbon sequestration in agriculture. Agricultural and Forest Meteorology 142:288-302.

InfoStat. 2011. Infostat/Estudiantil. Grupo Infostat/FCA, Universidad Nacional de Córdoba, Córdoba, Argentina.

IPCC. 2007. Cambio climático 2007: Informe de síntesis. 114 p. Intergovernmental Panel on Climate Change (IPCC), Cambridge University Press, Cambridge, UK.

Labraga, J., and R. Villalba. 2009. Climate in the Monte desert: past trends, present conditions, and future projections. Journal of Arid Environments 73:154-163.

Lal, R. 2011. Sequestering carbon in soils of agro-ecosystems. Food Policy 36:S33-S39.

Lambers, H., F.S. Chapin III, and T.L. Pons. 2008. Plant physiological ecology. Springer, New York, USA.

Medhurst, J., J.A.N. Parsby, S. Linder, G. Wallin, E. Ceschia, and M. Slaney. 2006. A whole-tree chamber system for examining tree-level physiological responses of field-grown trees to environmental variation and climate change. Plant, Cell \& Environment 29:1853-1869.

Müller, J., T. Behrens, and W. Diepenbrock. 2005. Measurement and modelling of canopy gas exchange of oilseed rape. Agricultural and Forest Meteorology 132:181-200.

Müller, J., A. Eschenröder, and W. Diepenbrock. 2009. Throughflow chamber $\mathrm{CO}_{2} / \mathrm{H}_{2} \mathrm{O}$ canopy gas exchange system. Construction, microclimate, errors, and measurements in a barley (Hordeum vulgare L.) field. Agricultural and Forest Meteorology 149:214-229.

Myklebust, M.C., L.E. Hipps, and R.J. Ryel. 2008. Comparison of eddy covariance, chamber, and gradient methods of measuring soil $\mathrm{CO}_{2}$ efflux in an annual semi-arid grass, Bromus tectorum. Agricultural and Forest Meteorology 148:1894-1907. 
Pérez-Priego, O., L. Testi, F. Orgaz, and F.J. Villalobos. 2010. A large closed canopy chamber for measuring $\mathrm{CO}_{2}$ and water vapour exchange of whole trees. Environmental and Experimental Botany 68:131-138.

Poni, S., M.C. Merli, E. Magnanini, M. Galbignani, F. Bernizzoni, A. Vercesi, et al.2014. An improved multichamber gas exchange system for determining whole canopy water use efficiency in the grapevine. American Journal of Enology and Viticulture 65:268-276.

Schrier-Uijl, A.P., P.S. Kroon, A. Hensen, P.A. Leffelaar, F. Berendse, and E.M. Veenendaal. 2010. Comparison of chamber and eddy covariance-based $\mathrm{CO}_{2}$ and $\mathrm{CH}_{4}$ emission estimates in a heterogeneous grass ecosystem on peat. Agricultural and Forest Meteorology 150:825-831.

Stannard,D.I., and M.A. Weltz.2006.Partitioningevapotranspiration in sparsely vegetated rangeland using a portable chamber. Water Resources Research 42:1-13.
Uliarte, E.M., C.A. Parera, E.E. Alessandria, y A.D. Dalmasso. 2014. Intercambio gaseoso y eficiencia en el uso del agua de cultivos de cobertura con especies nativas (Mendoza, Argentina), exóticas cultivadas y malezas. Agriscientia 31:49-61.

Uliarte, E.M., H.R. Schultz, C. Frings, M. Pfister, C.A. Parera, and R.F. del Monte. 2013. Seasonal dynamics of $\mathrm{CO}_{2}$ balance and water consumption of $\mathrm{C}_{3}$ and $\mathrm{C}_{4}$-type cover crops compared to bare soil in a suitability study for their use in vineyards in Germany and Argentina. Agricultural and Forest Meteorology 181:1-16.

Varela, S., G. Caballé, M. Curetti, y J. Portela. 2010. Sistemas IRGA en la medición de intercambio gaseoso. p. 89-108. In Fernández, M.E., and J.E. Gyenge (eds.) Técnicas de medición en ecofisiología vegetal. Ediciones INTA, Buenos Aires, Argentina. 